\title{
Process Simulation and Optimization of Anaerobic Co-Digestion
}

\author{
Abrar Inayat ${ }^{1 *}$, Shams Forruque Ahmed ${ }^{2 *}$, F. Djavanroodi ${ }^{3 *}$, Fatima Al-Ali ${ }^{1}$, Mira Alsallani ${ }^{1}$ \\ and Shama Mangoosh ${ }^{1}$ \\ ${ }^{1}$ Department of Sustainable and Renewable Energy Engineering, University of Sharjah, Sharjah, United Arab Emirates, ${ }^{2}$ Science \\ and Math Program, Asian University for Women, Chattogram, Bangladesh, ${ }^{3}$ Mechanical Engineering Department, Prince \\ Mohammad Bin Fahad University, Al Khobar, Saudi Arabia
}

Anaerobic digestion (AD) is an established method that has been extensively utilized for waste management, waste treatment, and biogas production. Anaerobic co-digestion (AcoD) is regarded as a practical approach to address substrate characteristics and system optimization issues. The distinction between AcoD and mono-digestion is that

OPEN ACCESS

Edited by:

Hossain M. Zabed,

Jiangsu University, China

Reviewed by:

Hafiz Muhammad Uzair Ayub, Yeungnam University, South Korea

Yi Zhang,

Guangzhou Institute of Energy Conversion (CAS), China

Arman Amani Babadi,

University of Malaya, Malaysia

*Correspondence: Abrar Inayat

ainayat@sharjah.ac.ae

Shams Forruque Ahmed shams.f.ahmed@gmail.com

F. Djavanroodi

fdjavanroodi@pmu.edu.sa

Specialty section:

This article was submitted to

Bioenergy and Biofuels,

a section of the journal

Frontiers in Energy Research

Received: 25 August 2021

Accepted: 11 October 2021

Published: 02 November 2021

Citation:

Inayat A, Ahmed SF, Djavanroodi F,

Al-Ali F, Alsallani $M$ and Mangoosh $S$ (2021) Process Simulation and

Optimization of Anaerobic Co-

Digestion.

Front. Energy Res. 9:764463. doi: 10.3389/fenrg.2021.764463
AcoD has a higher organic loading and significant substrate composition variation. There are many factors involved in AcoD which affect the biogas plant's production ability and performance. Using response surface methodology (RSM) to forecast the optimal conditions for maximum biogas output, this article provides an overview of the different operational parameters in the AcoD process, modeling of the AcoD process, and overall process optimization. Standard software used for AcoD process simulation are Aspen Plus, SuperPro Designer, BioWin, CFD, and MATLAB. Review addresses design, development, and optimization frameworks for biogas production systems that take numerous aspects into account. The most significant AcoD optimization parameters include temperature, co-substrate concentration, inoculum ratio (percent), and $\mathrm{C} / \mathrm{N}$ ratio.

Keywords: anaerobic co-digestion, biogas, simulation, optimization, response surface methodology

\section{INTRODUCTION}

Sustainable and renewable energies are significantly connected, available in abundance and considered sustainable like solar, wind, biomass, and geothermal. Sustainable energy is a form of energy that is free of cost and doesn't support the fear of expiry (Lu et al., 2020). The clean energy produced from non-depleted sources or can be replenished and has low emission of greenhouse gases is called renewable energy. All sources of renewable energy depend on the sun directly or indirectly. Biomass energy is a source of energy from living organisms like wood, agricultural wastes, and manure. Biomass can be converted into biofuels via different methods of conversion: thermal, chemical and biological (Mofijur et al., 2013a; Mofijur et al., 2013b; Yu et al., 2021). Anaerobic digestion $(\mathrm{AD})$ is a biological process that is carried out naturally through decomposition with respect to no oxygen presence; it allows microorganisms to digest organic matters to produce biogas which consists of hydrocarbon products (methane), leaving a stabilized solid product (digestate). Anaerobic digestion is commonly used for sewage treatment to stabilize the wastes (Hanum et al., 2019). Moreover, it has been used to treat industrial and farm waste lately (Uddin et al., 2021). Managing animal wastes has become essential for sustainable development and economic and environmental facts (Sakar et al., 2009).

Anaerobic co-digestion (AcoD) is a process that enhances the production of biogas by mixing more than substance in a digester with wastewater. Because of the diversity of waste available 
worldwide, it is regarded as one of the most active sources of renewable energy in the world (Neshat et al., 2017). The AcoD process supports waste management by using it to produce clean energy to reduce greenhouse gas emissions. Using animal manure and organic wastes as feedstocks for co-digestion to produce biogas is an attractive solution (Ahmed et al., 2021). It can be implemented by two methods of the agricultural biogas plants (Holm-Nielsen et al., 2009). The phenomena of joint biogas plants are pretty beneficial. It is conducted by collecting animal manure from different farms and co-digesting it with organic residues from various places such as feed industries. The digester capacities range from a few hundred up to several thousand cubic meters. The farm-scale plants are similar to the joint co-digestion plants, where the animal manure and wastes are collected from one or two neighboring farms. In addition, the $\mathrm{AcoD}$ process is used to enhance the biogas yield (Fraizer, 2011).

Several experimental studies have been conducted for biogas production using AcoD approach (Bond et al., 2012; Xie et al., 2018; Hallaji et al., 2019; Chow et al., 2020). An experimental work using a batch reactor has been reported for biogas production using sewage sludge and cow dung (Rao and Baral, 2011). It is also found that kitchen waste and poultry manure are potential candidates for biogas production (Rahman et al., 2021). Researchers showed that the AcoD of animal manure and food waste could produce a high amount of methane yield using batch and semi-continuous processes (Zhang et al., 2013).

In the best AcoD performance, numerous factors must come together. To optimize the co-digestion system's for higher methane yield, many factors such as temperature, $\mathrm{pH}, \mathrm{C} / \mathrm{N}$ ratio, particle size, substrate concentration and hydrolytic retention time will be critical (Siddique and Wahid, 2018). Studying different factors in a controlled environment is important to let the bacteria work at their maximum capacity for biogas generation. Applying mathematical and simulation models with these factors enables the co-digestion system to optimize and maximize methane production. As a result, research must be carried out to determine which simulation models can boost AcoD's performance for on-demand bioenergy production. A lack of information in the present models is also recognized, and the development of new models may result in the buildup of knowledge gaps as well. The AcoD optimization of variables is critical for better process performance and the identification of an energy-efficient and cost-effective system. According to the findings, the AcoD procedure and all of its aftereffects may be fully reproduced. For scientists and engineers interested in the fundamental principles of $\mathrm{AcoD}$, this article is a valuable resource.

\section{FACTORS AFFECTING ACOD}

Several parameters affect the overall performance of the anaerobic digestion process. The wastewater chemical properties, temperature, $\mathrm{pH}$ value, particle size, $\mathrm{C} / \mathrm{N}$ ratio, organic loading rate, hydraulic retention time, alkalinity have to be tested for the Co-digestion system to get the optimum methane generation (Xie et al., 2016). To choose the suitable wastewater for AcoD, it is helpful to know the chemical properties of different wastewater. It is hard to find the chemical compositions of substrates for the wastewater because there are different wastewater sources. For example, the sugars decomposed with acidogenesis forming volatile fatty acid have a high concentration of sugar, which enhances the concentration of volatile fatty acid and leads to low $\mathrm{pH}$ in digestion. Moreover, the substrates rich in protein can produce a large amount of methane from organic wastes like ethanol industry waste and farmhouse waste. Vapor fatty acids and/or excessive levels of ammonia can impede and reduce the anaerobic digestion process if the carbon-to-nitrogen ratios are not appropriate. In addition, the rate of biogas generation can be enhanced by mixing the rich carbohydrate materials with a fat-rich material (Siddique and Wahid, 2018; Chow et al., 2020; Tait et al., 2021).

The temperature has an impact on the $\mathrm{AD}$ process' microorganism function. As a result, it has an impact on biogas production. There are three types of temperature processes that may carry out $\mathrm{AD}$ : psychrophilic, thermophilic, and mesophilic. The gas production rate increases with raised temperature and the number of methane increases, so maintaining the temperature at constant value is required during the digestion process. The temperatures between 32 and $35^{\circ} \mathrm{C}$ make the production of methane most stable and continuous. Thus, the mesophilic process is more stable compared to others (Meegoda et al., 2018; Muthudineshkumar and Anand, 2019). The solubilization of organic matters and the fermentation to produce biogas are significantly affected by the $\mathrm{pH}$ concentration in the $\mathrm{AD}$ system. Even though most microorganisms prefer neutral $\mathrm{pH}$ concentrations between 6.8 and 7.2, different microorganisms need different values of optimal $\mathrm{pH}$. For example, the preferred value of $\mathrm{pH}$ for hydrolyzing and acidogenic microorganisms is within the 5.5-6.5 range. Moreover, as mentioned before, the $\mathrm{pH}$ concentration decreases with the accelerated production of volatile fatty acid. This affects biogas production. To solve this problem, an alkali chemical like $\mathrm{CaCO}_{3}$ is recommended to be added (Abdelgadir et al., 2014; Muthudineshkumar and Anand, 2019; Zhou and Wen, 2019).

The particle size of waste influences the digestion process for biogas production. The smaller the particle size, the easier and faster it is to process, whereas the more prominent the particle, the more complex and dangerous the process becomes since it may clog. Moreover, decreasing the particle size of food waste from 8 to $2.5 \mathrm{~mm}$ increases gas production by 10-29\% (Agyeman and Tao, 2014). C/N reflects the amount of carbon to the amount of nitrogen ratio present in an organic matter. The carbon is essential to provide a suitable substrate for $\mathrm{AD}$ and the nitrogen is necessary to feed the microorganisms on the proteins that are formatting from nitrogen (Meegoda et al., 2018). If the ratio of $\mathrm{C} / \mathrm{N}$ is low, that means nitrogen will be released and accumulated to form ammonia, leading to an increase in the value of $\mathrm{pH}$; therefore, biogas production will be reduced. Likewise, a high $\mathrm{C} / \mathrm{N}$ ratio will rapidly consume the nitrogen by methanogenic bacteria to meet their protein requirement. It will not react with carbon thus, causing a decrease in biogas production. However, for 
efficient biogas production $\mathrm{C} / \mathrm{N}$ ratio is usually adjusted by mixing waste of low ratio with those of high ratio (Alexandra et al., 2019).

Organic loading rate (OLR) presents the number of dry organics injected to a digester per unit time; high OLR desired less energy for heating, boosts different microbial species and decreases digester size and cost. At the same time, low OLR causes inefficient $\mathrm{AD}$ technology. However, there are limitations in increasing the OLR where higher ORL can damage the circulating pump, lower the heat transfer, and create highly volatile fatty acid and ethanol (Nkuna et al., 2021). The volume of the digester over the flow rate of the digester is considered the hydraulic retention time (HRT) and it means the length of time needed to consume microorganisms inside the digester. The HRT and OLR have an inversely proportional relation between each other.

The microorganisms might die because of a shortage of nutrients when the HRT is long thus, short HRT is recommended for industrial application to decrease the digester volume, lower cost, and maximize the production of biogas and production of net electrical energy (Meegoda et al., 2018; Shaojie et al., 2020). One of the most important parameters for the $\mathrm{AD}$ is alkalinity and it measures the capacity of an $\mathrm{AD}$ to neutralize the acid. It happens because of the salts of weak acids. For $\mathrm{AD}$, the maximum alkalinity as $\mathrm{CaCo}_{3}$ is between 1,000 and $5,000 \mathrm{mg} / \mathrm{L}$. Alkalinity increases with high HRT because at low HRT operation, the organic material has higher input. Even though alkalinity increases at the startup period until it reaches a steady-state, it will decrease in all reactors at the end, and this decrease can be controlled by adjusting the $\mathrm{pH}$ value (Lerdrattranataywee and Kaosol, 2015; Xuemei et al., 2018).

\section{MAIN AND CO-SUBSTRATE IN ACOD}

Cattle manure production in large-scale farms has increased around the world. Many environmental problems are caused by manure, such as greenhouse gas emissions, odor problems, the release of fecal coli-form bacteria and pathogens, surface and ground contamination, rodents, insects, flies and other pests (Tufaner and Avşar, 2016). Anaerobic digestion of cattle manure has been used for around 25-30 years (Callaghan et al., 2002), especially in the rural sector. This helps to decrease the negative outcomes of manure and produce valuable energy. However, the use of manure itself for biogas production was usually reported to have poor methane yield; thus, anaerobic co-digestion of manure with other biomass is recommended as it would be a cost-effective solution that would improve the efficiency of the process (Banks et al., 2011; Frigon et al., 2012).

Manure is a complex substrate made up of a large amount of dissolved and undissolved organic matter, such as proteins, lipids, and volatile fatty acids (VFA), and an abundant number of inorganic compounds (Hublin and Zelić, 2013). Furthermore, cattle manure contains complex lignin leftover from the fodder that the cattle intake, which is very resistant to $\mathrm{AD}$ process, thus limiting the biogas production. Manure is found to have a low
TABLE 1 | Common substrates used with cow manure for AcoD.

\begin{tabular}{lcl}
\hline Substrates & Mixing ratio & \multicolumn{1}{c}{ Reference } \\
\hline Olive mill waste & $3: 1$ & Goberna et al. (2010) \\
Fruits and Vegetable waste & $80: 20$ & Callaghan et al. (2002) \\
Grass silage & $90: 10$ & Lehtomäki et al. (2007) \\
Sugar beet by-products & $50: 50$ & Fang et al. (2011) \\
Crude glycerin & $95: 5$ & Robra et al. (2010) \\
Wheat straw & $50: 50$ & Hashimoto. (1983) \\
Cheese whey & $35: 65$ & Comino et al. (2012)
\end{tabular}

$\mathrm{C} / \mathrm{N}$ ratio which causes the ammonia concentrations to be higher than the requirement for microbial growth, where this could be restrictive to methanogens (Wang et al., 2012). Hence, cosubstrate high in $\mathrm{C} / \mathrm{N}$ ratio, or $\mathrm{C}$-rich substrate, are needed for the AcoD with manure to overcome the problems, keep the $\mathrm{pH}$ level stable, and finally increase methane production. Several studies have been conducted about the AcoD of cattle manure with other biomass wastes as co-substrates (Atandi and Rahman, 2012; Hagos et al., 2017; Ambaye et al., 2020).

Fruit and vegetable wastes (FVW) have been used in several studies as a digester feedstock (Ji et al., 2017). Yet, it was also found that the nitrogen and phosphorus contents can be low; thus, FVW is suggested for co-digestion rather than monodigestion (Bouallagui et al., 2009). Callaghan et al. (2002) showed that varying the ratio of manure to FVW affects the methane yield. Their results showed that increasing FVW from 20 to $50 \%$ increased methane yield from 0.23 to $0.45 \mathrm{~m}^{3} \mathrm{CH}_{4} / \mathrm{kg} \mathrm{VS}$. Moreover, the waste-water residue found in the dairy industry has high biodegradability. When is co-digested with low biodegradable manure would increase the methane yield, rather than when manure alone is used. Labatut et al. (2011) investigated pure manure and manure with co-substrate using different ratios for methane production. Results showed the methane yields were $252.4 \mathrm{ml} \mathrm{CH}_{4} / \mathrm{g}$ VS using Cheese whey as co-substrate compared to pure manure methane yield of $242.7 \mathrm{ml}$ $\mathrm{CH}_{4} / \mathrm{g}$ VS. The literature review showed that co-digestion of manure waste with other biomass waste could enhance the methane production, especially with easily-degradable carbohydrate-containing substrates. Table 1 showed the list of substrates used with cow manure in the AcoD process for methane production.

\section{SIMULATION AND OPTIMIZATION OF ACOD}

\section{Simulation of AcoD}

Experimental procedures can sometimes be expensive and timeconsuming, and results would be inaccurate; thus, simulations are usually preferred. Process simulations would result in incorrect results for real-life applications if appropriate assumptions and software were used. However, minimal studies have been done on the simulations of AcoD. Literature showed that many researchers used anaerobic digestion model no 1 (ADM1) to simulate the AcoD process (García-Gen et al., 2013; Shi et al., 2014). Fezzani and Cheikh (2009) simulated the AcoD process of 


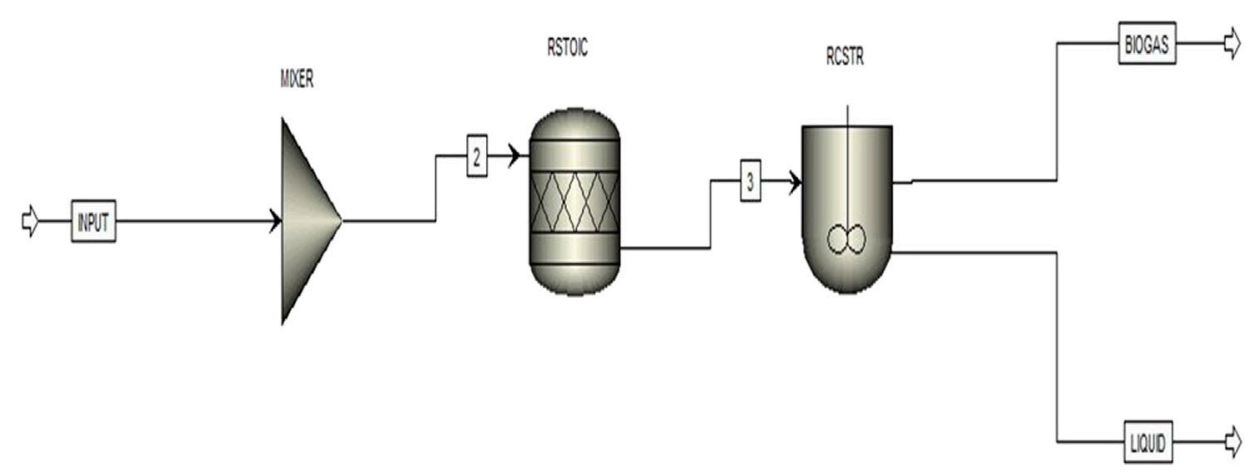

FIGURE 1 | A simulation model for AcoD using Aspen Plus (Inayat et al., 2019).

phenol compounds, olive mill wastewater, and solid waste using ADM1. There are few simulations performed for the AcoD process using municipal solid waste organic fractions and sewage sludge via the ADM1 modeling approach (Derbal et al., 2009; Esposito et al., 2011).

Simulation studies are available for AD using Aspen Plus software (Rajendran et al., 2014; Aguilar et al., 2017; Ravendran et al., 2019), but limited studies were found in which simulation was used to evaluate AcoD (Nduse and Oladiran, 2016; Inayat et al., 2019; Ankathi et al., 2021). Aspen Plus (AP) software is a chemical process simulator that allows users to design and simulate a process model or improve existing designs using complex equations. Various industrial modules are built in the system, by which different process flow sheets can be conducted and simulated by interconnecting modules. The advantage of the AP software is that it can simulate the actual plant behavior, as it applies fundamental engineering relationships for mass and energy balances and phase and chemical equilibrium (Nduse and Oladiran, 2016).

Inayat et al. (2019) used Aspen Plus to simulate the AcoD for biogas production using wastewater and animal manure as main substrates and compared results from using five cases of different ratios of co-substrates. The results obtained were the mole fractions of $\mathrm{CO}_{2}$ and $\mathrm{CH}_{4}$ in the biogas and sludge produced for all cases. It was found that using date tree leaves as a cosubstrate with manure and wastewater at a ratio of $25 \% \mathrm{M}: 50 \%$ WW: 25\% DTL would result in a high yield of $\mathrm{CH}_{4}$ of around $50.55 \mathrm{~mol} \%$, but the $\mathrm{CO}_{2}$ emission was high; thus, the ratio of $\mathrm{CH}_{4} / \mathrm{CO}_{2}$ was low. On the other hand, it was also found that using date seeds as a co-substrate with a ratio of $25 \% \mathrm{M}: 50 \% \mathrm{WW}: 25 \%$ DS achieved $47.85 \mathrm{~mol} \%$ of $\mathrm{CH}_{4}$, yet its $\mathrm{CH}_{4} / \mathrm{CO}_{2}$ ratio was much higher, which means that the $\mathrm{CO}_{2}$ emission is lower and this is more appealing and recommended. Figure 1 shows the simple simulation model using Aspen Plus software.

Nduse and Oladiran (2016) used another method known as the stoichiometry method, mainly using the degradation paths as the reaction phases. The paths only included carbohydrates and proteins and excluded fats since the fats do not have $\mathrm{CH}_{4}$ or $\mathrm{CO}_{2}$ in their end products. In addition, the mass composition of the carbohydrates and proteins of the feedstock are required to carry out the simulation. The simulation results were done for three cases, kitchen waste only, cow dung only, and co-digestion of both kitchen waste and cow dung. On the other hand, (Kovalovszki et al., 2017) presented a systematic approach for simulation using MATLAB as software for the simulation of AcoD process using manure, wastewater and different organic subtracts. Simulation results showed agreement with the experimental data.

The simulation method can be the simplest way to conduct the parametric study for AcoD using Aspen Plus software for efficient results. Nevertheless, the software has several modules in the library that can be used; it depends on the complexity and precision that the user wants to have. Furthermore, a variety of different software can also be used to simulate anaerobic digestion, such as Aquasim, BioWin, Simba, STOAT (Sewage Treatment Operation Analysis over Time), and WEST (Worldwide Engine for Simulation, Training and Automation).

\section{Optimization of AcoD}

To maximize biogas production, process parameter optimization is critical. Optimization of AcoD for the process parameters serves additional study opportunities: ways to improve the efficiency and time spent on the process and opportunities to explore new possibilities. During optimization, several process parameters should be taken into consideration to check the possibility of a higher yield of biogas and an efficient and cost-effective process. The optimization and prediction of the anaerobic process can be significantly aided by artificial intelligence approaches such as neural networks, fuzzy logic, and expert systems.

More work needs to be done on optimizing AcoD under different digestion circumstances. Optimization of process parameters using the Response surface methodology (RSM) approach is considered an effective tool for AcoD process. Optimization using RSM is a set of mathematical and statistical techniques for modeling and analyzing the effects of multiple variables in a single variable. Furthermore, RSM is a time-saving approach for designing experiments used by predicting the coefficients in a mathematical model. Several studies have been conducted for AcoD optimization using RSM. Table 2 showed the list of optimization studies for AcoD using RSM. The maximum yield of biogas (or methane) 
TABLE 2 | AcoD parameters optimization using RSM.

\begin{tabular}{|c|c|c|c|c|}
\hline Substrates & Variables for optimization & Optimum conditions & $\begin{array}{l}\text { Max. Methane at } \\
\text { optimum conditions (ml } \\
\mathrm{CH}_{4} / \mathrm{g} \text { VS.) }\end{array}$ & Ref \\
\hline \multirow[t]{4}{*}{ Cow dung and flower waste } & Temperature $\left({ }^{\circ} \mathrm{C}\right)$ & 50 & 568 & Lakshmi et al. (2021) \\
\hline & $\mathrm{pH}$ & 7.2 & & \\
\hline & Substrate concentration (kg) & 100 & & \\
\hline & Agitation time (s) & 5 & & \\
\hline \multirow[t]{4}{*}{ Dairy manure (DM), chicken manure $(\mathrm{CM})$ and wheat straw } & $\mathrm{C} / \mathrm{N}$ ratio & 26.31 & 394 & Wang et al. (2013) \\
\hline & Feeding composition & $42.96: 57.04$ & & \\
\hline & Initial loading (g VS/L) & 15.90 & & \\
\hline & Inoculum-to-substrate ratio & 2.34 & & \\
\hline \multirow[t]{3}{*}{ Peanut hulls and swine manure } & TS\% & 5.85 & 686.06 & Deng et al. (2019) \\
\hline & $\mathrm{C} / \mathrm{N}$ ratio & $34.06: 1$ & & \\
\hline & Inoculum ratio (\%) & 30 & & \\
\hline \multirow[t]{3}{*}{ Rice straw and food waste } & $\mathrm{C} / \mathrm{N}$ ratio & 30 & 323.78 & Jyoti et al. (2020) \\
\hline & Food/microorganisms & 1.87 & & \\
\hline & Initial pH & 7.32 & & \\
\hline \multirow[t]{2}{*}{ Dairy manure (DM), chicken manure $(\mathrm{CM})$ and wheat straw } & $\mathrm{DM} / \mathrm{CM}$ & 40.3:59.7 & 247.5 & Xiaojiao et al. (2012) \\
\hline & $\mathrm{C} / \mathrm{N}$ ratio & $27.2: 1$ & & \\
\hline \multirow[t]{4}{*}{ Poultry manure and food waste } & Solid concentration & 7.38 & $6,344 \mathrm{ml}$ of biogas & Deepanraj et al. (2021) \\
\hline & $\mathrm{pH}$ & 7 & & \\
\hline & Temperature $\left({ }^{\circ} \mathrm{C}\right)$ & 48.43 & & \\
\hline & Co-digestion (\%) & 29 & & \\
\hline
\end{tabular}

to the optimum parameters has also been summarized in Table 2 . Different parameters are used for optimization, but temperature, co-substrate concentration, inoculum ratio (\%) and $\mathrm{C} / \mathrm{N}$ ratio are the most critical parameters for AcoD optimization. Results showed that methane yield interacted significantly with the chosen parameters. By increasing the number of volatile solids accessible, high substrate-to-inoculum ratios lead to high methane outputs. It is also observed that the high substrate to inoculum ratios might limit methanogenic bacteria and effect the methane production. Cow dung co-substrate has a carbon-tonitrogen ratio of $15-35$, according to recent research. The AcoD process's performance is also influenced by $\mathrm{pH}$. Despite the fact that research has proven that a $\mathrm{pH}$ of 7.0 is optimal for the AcoD process.

\section{CONCLUSION}

Producing biogas by using AcoD technology is considered a convenient source of energy rather than fossil fuel. Different factors that affect the AcoD process were stated. The RSM approach discussed simulation and optimization for the AcoD system to predict optimum parameters for maximum methane production. One of the important factors leading to improvements in AcoD technology is the interdependence of many components. When only one of these components is researched, the results may not be trustworthy. Biogas output may be boosted and the co-digestion process optimized with online measurements of key parameters. One of the primary future goals is to reduce capital expenditures. Optimization methods should be used to modify the ratio, concentration, and particle size of feedstock as well as mix various residues most efficiently. Investigations about sulfur, phosphorus, and nitrogen should have more focus, and a continuous fed digestion process must be studied to understand the interactions between AcoD factors. In addition, using the AcoD for the industrial application requires an appropriate simulation model using advanced software.

\section{AUTHOR CONTRIBUTIONS}

AI-conceptualization, original draft; SA-draft, review and editing; FD-review and funding acquisition, FA-A-resources, review and editing, MA-review and editing, SM-review and editing.

\section{ACKNOWLEDGMENTS}

The authors extend their appreciation to Prince Mohammad Bin Fahd University for funding this research work. 


\section{REFERENCES}

Abdelgadir, A., Chen, X., Liu, J., Xie, X., Zhang, J., Zhang, K., et al. (2014). Characteristics, Process Parameters, and Inner Components of Anaerobic Bioreactors. Biomed. Res. Int. 2014, 841573. doi:10.1155/2014/841573

Aguilar, M. C., Wang, Y. D., Roskilly, T., Pathare, P. B., and Lamidi, R. O. (2017). Biogas from Anaerobic Co-digestion of Food Waste and Primary Sludge for Cogeneration of Power and Heat. Energ. Proced. 142, 70-76. doi:10.1016/ j.egypro.2017.12.012

Agyeman, F. O., and Tao, W. (2014). Anaerobic Co-digestion of Food Waste and Dairy Manure: Effects of Food Waste Particle Size and Organic Loading Rate. J. Environ. Manage. 133, 268-274. doi:10.1016/j.jenvman.2013.12.016

Ahmed, S. F., Mofijur, M., Tarannum, K., Chowdhury, A. T., Rafa, N., Nuzhat, S., et al. (2021). Biogas Upgrading, Economy and Utilization: a Review. Environ. Chem. Lett., 1-28. doi:10.1007/s10311-021-01292-x

Alexandra, C.-V., Karen Tatiana Cáceres, C., Alejandro Rincón, P., and Álvaro Andrés Cajigas, C. (2019). Influence of $\mathrm{pH}$ and the C/N Ratio on the Biogas Production of Wastewater. Revista Facultad de Ingeniería Universidad de Antioquia, 70-79. doi:10.17533/udea.redin.20190627

Ambaye, T. G., Rene, E. R., Dupont, C., Wongrod, S., and Van Hullebusch, E. D. (2020). Anaerobic Digestion of Fruit Waste Mixed with Sewage Sludge Digestate Biochar: Influence on Biomethane Production. Front. Energ. Res. 8, 31. doi:10.3389/fenrg.2020.00031

Ankathi, S., Watkins, D., Sreedhara, P., Zuhlke, J., and Shonnard, D. R. (2021). GISintegrated Optimization for Locating Food Waste and Manure Anaerobic Codigestion Facilities. ACS Sustain. Chem. Eng. 9, 4024-4032. doi:10.1021/ acssuschemeng.0c07482

Atandi, E., and Rahman, S. (2012). Prospect of Anaerobic Co-digestion of Dairy Manure: a Review. Environ. Techn. Rev. 1, 127-135. doi:10.1080/ 09593330.2012.698654

Banks, C. J., Salter, A. M., Heaven, S., and Riley, K. (2011). Energetic and Environmental Benefits of Co-digestion of Food Waste and Cattle Slurry: A Preliminary Assessment. Resour. Conservation Recycling 56, 71-79. doi:10.1016/j.resconrec.2011.09.006

Bond, T., Brouckaert, C. J., Foxon, K. M., and Buckley, C. A. (2012). A Critical Review of Experimental and Predicted Methane Generation from Anaerobic Codigestion. Water Sci. Technol. 65, 183-189. doi:10.2166/wst.2011.845

Bouallagui, H., Lahdheb, H., Ben Romdan, E., Rachdi, B., and Hamdi, M. (2009). Improvement of Fruit and Vegetable Waste Anaerobic Digestion Performance and Stability with Co-substrates Addition. J. Environ. Manage. 90, 1844-1849. doi:10.1016/j.jenvman.2008.12.002

Callaghan, F. J., Wase, D. A. J., Thayanithy, K., and Forster, C. F. (2002). Continuous Co-digestion of Cattle Slurry with Fruit and Vegetable Wastes and Chicken Manure. Biomass and Bioenergy 22, 71-77. doi:10.1016/s09619534(01)00057-5

Chow, W. L., Chong, S., Lim, J. W., Chan, Y. J., Chong, M. F., Tiong, T. J., et al. (2020). Anaerobic Co-digestion of Wastewater Sludge: A Review of Potential Co-substrates and Operating Factors for Improved Methane Yield. Processes 8, 39. doi:10.3390/pr8010039

Comino, E., Riggio, V. A., and Rosso, M. (2012). Biogas Production by Anaerobic Co-digestion of Cattle Slurry and Cheese Whey. Bioresour. Techn. 114, 46-53. doi:10.1016/j.biortech.2012.02.090

Deepanraj, B., Senthilkumar, N., Ranjitha, J., Jayaraj, S., and Ong, H. C. (2021). Biogas from Food Waste through Anaerobic Digestion: Optimization with Response Surface Methodology. Biomass Conv. Bioref. 11, 227-239. doi:10.1007/s13399-020-00646-9

Deng, Y., Qiu, L., Shao, Y., and Yao, Y. (2019). Process Modeling and Optimization of Anaerobic Co-digestion of Peanut Hulls and Swine Manure Using Response Surface Methodology. Energy Fuels 33, 11021-11033. doi:10.1021/ acs.energyfuels.9b02381

Derbal, K., Bencheikh-Lehocine, M., Cecchi, F., Meniai, A.-H., and Pavan, P. (2009). Application of the IWA ADM1 Model to Simulate Anaerobic Co-digestion of Organic Waste with Waste Activated Sludge in Mesophilic Condition. Bioresour. Techn. 100, 1539-1543. doi:10.1016/j.biortech.2008.07.064

Esposito, G., Frunzo, L., Panico, A., and Pirozzi, F. (2011). Modelling the Effect of the OLR and OFMSW Particle Size on the Performances of an Anaerobic
Co-digestion Reactor. Process Biochem. 46, 557-565. doi:10.1016/ j.procbio.2010.10.010

Fang, C., Boe, K., and Angelidaki, I. (2011). Anaerobic Co-digestion of By-Products from Sugar Production with Cow Manure. Water Res. 45, 3473-3480. doi:10.1016/j.watres.2011.04.008

Fezzani, B., and Cheikh, R. B. (2009). Extension of the Anaerobic Digestion Model No. 1 (ADM1) to Include Phenolic Compounds Biodegradation Processes for the Simulation of Anaerobic Co-digestion of Olive Mill Wastes at Thermophilic Temperature. J. Hazard. Mater. 162, 1563-1570. doi:10.1016/ j.jhazmat.2008.06.127

Fraizer, R. S. (2011). Anaerobic Digestion: Biogas Utilization and Cleanup.

Frigon, J.-C., Roy, C., and Guiot, S. R. (2012). Anaerobic Co-digestion of Dairy Manure with Mulched Switchgrass for Improvement of the Methane Yield. Bioproc. Biosyst Eng 35, 341-349. doi:10.1007/s00449-011-0572-5

García-Gen, S., Lema, J. M., and Rodríguez, J. (2013). Generalised Modelling Approach for Anaerobic Co-digestion of Fermentable Substrates. Bioresour. Techn. 147, 525-533. doi:10.1016/j.biortech.2013.08.063

Goberna, M., Schoen, M. A., Sperl, D., Wett, B., and Insam, H. (2010). Mesophilic and Thermophilic Co-fermentation of Cattle Excreta and Olive Mill Wastes in Pilot Anaerobic Digesters. Biomass and Bioenergy 34, 340-346. doi:10.1016/ j.biombioe.2009.11.005

Hagos, K., Zong, J., Li, D., Liu, C., and Lu, X. (2017). Anaerobic Co-digestion Process for Biogas Production: Progress, Challenges and Perspectives. Renew. Sustain. Energ. Rev. 76, 1485-1496. doi:10.1016/j.rser.2016.11.184

Hallaji, S. M., Kuroshkarim, M., and Moussavi, S. P. (2019). Enhancing Methane Production Using Anaerobic Co-digestion of Waste Activated Sludge with Combined Fruit Waste and Cheese Whey. BMC Biotechnol. 19, 19. doi:10.1186/ s12896-019-0513-y

Hanum, F., Yuan, L. C., Kamahara, H., Aziz, H. A., Atsuta, Y., Yamada, T., et al. (2019). Treatment of Sewage Sludge Using Anaerobic Digestion in Malaysia: Current State and Challenges. Front. Energ. Res. 7, 19. doi:10.3389/ fenrg.2019.00019

Hashimoto, A. G. (1983). Conversion of Straw-Manure Mixtures to Methane at Mesophilic and Thermophilic Temperatures. Biotechnol. Bioeng. 25, 185-200. doi:10.1002/bit.260250115

Holm-Nielsen, J. B., Al Seadi, T., and Oleskowicz-Popiel, P. (2009). The Future of Anaerobic Digestion and Biogas Utilization. Bioresour. Techn. 100, 5478-5484. doi:10.1016/j.biortech.2008.12.046

Hublin, A., and Zelić, B. (2013). Modelling of the Whey and Cow Manure Codigestion Process. Waste Manag. Res. 31, 353-360. doi:10.1177/ $0734242 \times 12455088$

Inayat, A., Raza, M., Ghenai, C., Shanableh, A., Said, Z., Samman, S., et al. (2019) "Simulation of Anaerobic Co-digestion Process for the Biogas Production Using ASPEN PLUS," in 2019 Advances in Science and Engineering Technology International Conferences (ASET), Dubai, United Arab Emirates, March 26-28, 2019, 1-5. doi:10.1109/icaset.2019.8714403

Ji, C., Kong, C.-X., Mei, Z.-L., and Li, J. (2017). A Review of the Anaerobic Digestion of Fruit and Vegetable Waste. Appl. Biochem. Biotechnol. 183, 906-922. doi:10.1007/s12010-017-2472-x

Jyoti, K., Ajay, S. K., and Vaibhav, V. G. (2020). Optimization of Process Parameters for Accelerated Methane Yield from Anaerobic Co-digestion of rice Straw and Food Waste. Renew. Energ. 149, 1352-1359. doi:10.1016/ j.renene.2019.10.124

Kovalovszki, A., Alvarado-Morales, M., Fotidis, I. A., and Angelidaki, I. (2017). A Systematic Methodology to Extend the Applicability of a Bioconversion Model for the Simulation of Various Co-digestion Scenarios. Bioresour. Techn. 235, 157-166. doi:10.1016/j.biortech.2017.03.101

Labatut, R. A., Angenent, L. T., and Scott, N. R. (2011). Biochemical Methane Potential and Biodegradability of Complex Organic Substrates. Bioresour. Techn. 102, 2255-2264. doi:10.1016/j.biortech.2010.10.035

Lakshmi, C. G., Marimuthu, G., Kavipriya, M. R., Shahid, M., Khalid, A. a.-G., Virik, P., et al. (2021). Optimization Strategies for Improved Biogas Production by Recycling of Waste through Response Surface Methodology and Artificial Neural Network: Sustainable Energy Perspective Research. J. King Saud Univ. Sci. 33, 101241. doi:10.1016/j.jksus.2020.101241

Lehtomäki, A., Huttunen, S., and Rintala, J. A. (2007). Laboratory Investigations on Co-digestion of Energy Crops and Crop Residues with Cow Manure for 
Methane Production: Effect of Crop to Manure Ratio. Resour. Conservation Recycling 51, 591-609. doi:10.1016/j.resconrec.2006.11.004

Lerdrattranataywee, W., and Kaosol, T. (2015). Effect of Mixing Time on Anaerobic Co-digestion of Palm Oil Mill Waste and Block Rubber Wastewater. Energ. Proced. 79, 327-334. doi:10.1016/j.egypro.2015.11.499

Lu, Y., Khan, Z. A., Alvarez-Alvarado, M. S., Zhang, Y., Huang, Z., and Imran, M. (2020). A Critical Review of Sustainable Energy Policies for the Promotion of Renewable Energy Sources. A Crit. Rev. Sustain. Energ. Policies Promot. Sustainability 12, 5078. doi:10.3390/su12125078

Meegoda, J. N., Li, B., Patel, K., and Wang, L. B. (2018). A Review of the Processes, Parameters, and Optimization of Anaerobic Digestion. Int. J. Environ. Res. Public Health 15. doi:10.3390/ijerph15102224

Mofijur, M., Atabani, A. E., Masjuki, H. H., Kalam, M. A., and Masum, B. M. (2013a). A Study on the Effects of Promising Edible and Non-edible Biodiesel Feedstocks on Engine Performance and Emissions Production: A Comparative Evaluation. Renew. Sustain. Energ. Rev. 23, 391-404. doi:10.1016/ j.rser.2013.03.009

Mofijur, M., Masjuki, H. H., Kalam, M. A., and Atabani, A. E. (2013b). Evaluation of Biodiesel Blending, Engine Performance and Emissions Characteristics of Jatropha Curcas Methyl Ester: Malaysian Perspective. Energy 55, 879-887. doi:10.1016/j.energy.2013.02.059

Muthudineshkumar, R., and Anand, R. (2019). Anaerobic Digestion of Various Feedstocks for Second-Generation Biofuel Production. Sawston, United Kingdom: Woodhead Publishing Series in Energy, 157-185. doi:10.1016/ b978-0-08-102728-8.00006-1

Nduse, R., and Oladiran, T. M. (2016). "Simulation of a Co-digester Plant Using aspen Plus," in Proceedings of the 5th IASTED International Conference on Power and Energy Systems, AfricaPES, 325-332. doi:10.2316/P.2016.839-008

Neshat, S. A., Mohammadi, M., Najafpour, G. D., and Lahijani, P. (2017). Anaerobic Co-digestion of Animal Manures and Lignocellulosic Residues as a Potent Approach for Sustainable Biogas Production. Renew. Sustain. Energ. Rev. 79, 308-322. doi:10.1016/j.rser.2017.05.137

Nkuna, R., Roopnarain, A., Rashama, C., and Adeleke, R. (2021). Insights into Organic Loading Rates of Anaerobic Digestion for Biogas Production: a Review. Crit. Rev. Biotechnol., 1-21. doi:10.1080/07388551.2021.1942778

Rahman, M. A., Shahazi, R., Nova, S. N. B., Uddin, M. R., Hossain, M. S., and Yousuf, A. (2021). Biogas Production from Anaerobic Co-digestion Using Kitchen Waste and Poultry Manure as Substrate-Part 1: Substrate Ratio and Effect of Temperature. Biomass Convers. biorefinery, 1-11. doi:10.1007/s13399021-01604-9

Rajendran, K., Kankanala, H. R., Lundin, M., and Taherzadeh, M. J. (2014). A Novel Process Simulation Model (PSM) for Anaerobic Digestion Using Aspen Plus. Bioresour. Techn. 168, 7-13. doi:10.1016/j.biortech.2014.01.051

Rao, P. V., and Baral, S. S. (2011). Experimental Design of Mixture for the Anaerobic Co-digestion of Sewage Sludge. Chem. Eng. J. 172, 977-986. doi:10.1016/j.cej.2011.07.010

Ravendran, R. R., Abdulrazik, A., and Zailan, R. (2019). Aspen Plus Simulation of Optimal Biogas Production in Anaerobic Digestion Process. IOP Conf. Ser. Mater. Sci. Eng. 702, 012001. doi:10.1088/1757-899x/702/1/012001

Robra, S., Serpa Da Cruz, R., De Oliveira, A. M., Neto, J. A. A., and Santos, J. V. (2010). Generation of Biogas Using Crude Glycerin from Biodiesel Production as a Supplement to Cattle Slurry. Biomass and Bioenergy 34, 1330-1335. doi:10.1016/j.biombioe.2010.04.021

Sakar, S., Yetilmezsoy, K., and Kocak, E. (2009). Anaerobic Digestion Technology in Poultry and Livestock Waste Treatment - a Literature Review. Waste Manag. Res. 27, 3-18. doi:10.1177/0734242x07079060

Shaojie, B., Xiujie, H., Hongzhi, Y., Xinhui, Y., Shumei, F., Yan, B., et al. (2020). Effect of Hydraulic Retention Time on Anaerobic Co-digestion of Cattle Manure and Food Waste. Renew. Energ. 150, 213-220. doi:10.1016/ j.renene.2019.12.091

Shi, X.-S., Yuan, X.-Z., Wang, Y.-P., Zeng, S.-J., Qiu, Y.-L., Guo, R.-B., et al. (2014). Modeling of the Methane Production and $\mathrm{pH}$ Value during the Anaerobic Codigestion of Dairy Manure and Spent Mushroom Substrate. Chem. Eng. J. 244, 258-263. doi:10.1016/j.cej.2014.02.007
Siddique, M. N. I., and Wahid, Z. A. (2018). Achievements and Perspectives of Anaerobic Co-digestion: A Review. J. Clean. Prod. 194, 359-371. doi:10.1016/ j.jclepro.2018.05.155

Tait, S., Harris, P. W., and Mccabe, B. K. (2021). Biogas Recovery by Anaerobic Digestion of Australian Agro-Industry Waste: A Review. J. Clean. Prod. 299, 126876. doi:10.1016/j.jclepro.2021.126876

Tufaner, F., and Avşar, Y. (2016). Effects of Co-substrate on Biogas Production from Cattle Manure: a Review. Int. J. Environ. Sci. Technol. 13, 2303-2312. doi:10.1007/s13762-016-1069-1

Uddin, M. N., Siddiki, S. Y. A., Mofijur, M., Djavanroodi, F., Hazrat, M. A., Show, P. L., et al. (2021). Prospects of Bioenergy Production from Organic Waste Using Anaerobic Digestion Technology: A Mini Review. Front. Energy Res. 9, 627093. doi:10.3389/fenrg.2021.627093

Wang, X., Yang, G., Feng, Y., Ren, G., and Han, X. (2012). Optimizing Feeding Composition and Carbon-Nitrogen Ratios for Improved Methane Yield during Anaerobic Co-digestion of Dairy, Chicken Manure and Wheat Straw. Bioresour. Techn. 120, 78-83. doi:10.1016/j.biortech.2012.06.058

Wang, X., Yang, G., Li, F., Feng, Y., and Ren, G. (2013). Response Surface Optimization of Methane Potentials in Anaerobic Co-digestion of Multiple Substrates: Dairy, Chicken Manure and Wheat Straw. Waste Manag. Res. 31, 60-66. doi:10.1177/0734242x12468197

Xiaojiao, W., Gaihe, Y., Yongzhong, F., Guangxin, R., and Xinhui, H. (2012). Optimizing Feeding Composition and Carbon-Nitrogen Ratios for Improved Methane Yield during Anaerobic Co-digestion of Dairy, Chicken Manure and Wheat Straw. Bioresour. Techn. 120, 78-83. doi:10.1016/j.biortech.2012.06.058

Xie, S., Hai, F. I., Zhan, X., Guo, W., Ngo, H. H., Price, W. E., et al. (2016). Anaerobic Co-digestion: A Critical Review of Mathematical Modelling for Performance Optimization. Bioresour. Techn. 222, 498-512. doi:10.1016/j.biortech.2016.10.015

Xie, S., Higgins, M. J., Bustamante, H., Galway, B., and Nghiem, L. D. (2018). Current Status and Perspectives on Anaerobic Co-digestion and Associated Downstream Processes. Environ. Sci. Water Res. Technol. 4, 1759-1770. doi:10.1039/c8ew00356d

Xuemei, W., Xue, B., Zifu, L., Xiaoqin, Z., Shikun, C., Jiachen, S., et al. (2018). Evaluation of Artificial Neural Network Models for Online Monitoring of Alkalinity in Anaerobic Co-digestion System. Biochem. Eng. J. 140, 85-92. doi:10.1016/j.bej.2018.09.010

Yu, Q., Wang, Y., Van Le, Q., Yang, H., Hosseinzadeh-Bandbafha, H., Yang, Y., et al. (2021). An Overview on the Conversion of Forest Biomass into Bioenergy. Front. Energ. Res. 9, 684234. doi:10.3389/fenrg.2021.684234

Zhang, C., Xiao, G., Peng, L., Su, H., and Tan, T. (2013). The Anaerobic Codigestion of Food Waste and Cattle Manure. Bioresour. Techn. 129, 170-176. doi:10.1016/j.biortech.2012.10.138

Zhou, H., and Wen, Z. (2019). "Solid-State Anaerobic Digestion for Waste Management and Biogas Production," in Solid State Fermentation: Research and Industrial Applications. Editors S. Steudler, A. Werner, and J. J. Cheng (Cham: Springer International Publishing), 147-168. doi:10.1007/10_2019_86

Conflict of Interest: The authors declare that the research was conducted in the absence of any commercial or financial relationships that could be construed as a potential conflict of interest.

Publisher's Note: All claims expressed in this article are solely those of the authors and do not necessarily represent those of their affiliated organizations, or those of the publisher, the editors and the reviewers. Any product that may be evaluated in this article, or claim that may be made by its manufacturer, is not guaranteed or endorsed by the publisher.

Copyright $\odot 2021$ Inayat, Ahmed, Djavanroodi, Al-Ali, Alsallani and Mangoosh. This is an open-access article distributed under the terms of the Creative Commons Attribution License (CC BY). The use, distribution or reproduction in other forums is permitted, provided the original author(s) and the copyright owner(s) are credited and that the original publication in this journal is cited, in accordance with accepted academic practice. No use, distribution or reproduction is permitted which does not comply with these terms. 